\title{
EKSPLORASI DAN IDENTIFIKASI CENDAWAN ANTAGONIS TERHADAP JAMUR AKAR PUTIH (Rigidoporus lignosus) PADA TANAMAN PALA (Myristica fragrans Houtt)
}

\author{
Nana Ariska ${ }^{1 *}$, Lola Adres Yanti ${ }^{1)}$ dan Chairudin ${ }^{1)}$ \\ ${ }^{1}$ Program Studi Agroteknologi Fakultas Pertanian Universitas Teuku Umar, Alue Penyareng 23615 \\ ${ }^{*}$ Email Korespondensi : nanaariska@utu.ac.id_23615
}

\begin{abstract}
Nutmeg (Myristica fragrans Houtt) is a multipurpose plantation commodity crop that almost all parts of the plant have strategic economic value to be cultivated. In Indonesia there are the largest nutmeg commodity centers, including the Maluku islands, North Sulawesi and Aceh. The biggest problem with nutmeg plants is the attack of pests and diseases. One of the most severe diseases in nutmeg is white root mushroom (Rigidoporus lignosus). This study aims to 1) determine the fungus of white root fungus antagonists (Rigodoporus lignosus) from the Aceh nutmeg rhizosphere (Myristica fragrans Houtt), 2) identify the content of antibiotic fungus JAP antagonist compounds in Aceh nutmeg plants. The study was conducted by taking soil samples from nutmeg plants at three nutmeg plantations in South Aceh. The antagonist fungus isolation activity uses a dilution method. Isolation of JAP from infected roots using direct planting method. Furthermore, it is identified macroscopically and microscopically. The antagonist test was carried out using the dual culture method with RAL. From the rhizosphere in the nutmeg area, 5 candidate antagonist isolates were obtained, having high in vitro antagonism ability to the pathogen $R$. lignosus. Identification results showed that isolates 1, 2 and 3 were Trichoderma spp, and isolates 4 and 5 were Gliocladium virens.
\end{abstract}

Keywords: In vitro, the content of antibiotic compounds, Aceh nutmeg, Rigidoporus lignosus, antagonistic test

\section{PENDAHULUAN}

Tanaman pala (Myristica fragrans Houtt) adalah tanaman asli Indonesia yang berasal dari pulau Banda. Bagian buah pala yang paling tinggi nilai ekonominya adalah biji dan fuli. Biji umumnya digunakan pada makanan manis dan kaya rempah, seperti produk roti dan juga sebagai bumbu dalam masakan daging serta produk minuman dan makanan penutup (dessert). Sementara itu, fuli digunakan sebagai bahan penambah rasa pada produk roti, seperti cake, cookies, pie, dan topping, juga sebagai bumbu pada masakan laut, pikel dan minuman (Rosyali 2016).

Biji dan fuli tanaman pala merupakan bahan ekspor hasil perkebunan yang cukup penting. Indonesia merupakan negara pengekspor biji pala dan fuli terbesar di pasaran dunia. Hingga saat ini diperkirakan $85 \%$ kebutuhan pala di pasaran dunia berasal dari Indonesia dan sisanya dipenuhi dari negara lainnya seperti Grenada, India, Srilangka dan Papua Newgini. Di Provinsi Aceh, sentra perkebunan pala adalah di Aceh Selatan. Data Dinas Tanaman Pangan dan Holtikultura Aceh Selatan menyebutkan bahwa pada tahun 2001, Aceh Selatan mampu menghasilkan 4.937 ton pala dengan devisa sedikitnya Rp 6,5 milyar. Tahun 1995 sampai 2000, rata-rata terjadi penurunan produksi 320 ton setiap tahun. Pada tahun 2005, produksi pala hanya 
mencapai 4.321 ton, dan tahun 2011 hanya terjadi sedikit peningkatan produksi yaitu menjadi 4.650 ton $^{1}$.

Sejak tahun 1990, kebun pala Aceh mengalami masalah serangan hama dan penyakit. Salah satu penyakit yang menyerang parah tanaman pala adalah jamur akar putih (JAP) yang disebabkan oleh Rigidoporus lignosus. Jamur akar putih menjadi penyakit yang sangat penting karena penyebabnya memiliki kisaran inang yang luas. Selain menyerang karet, jamur akar putih dapat menyerang teh, kopi, kakao, kelapa sawit, mangga, nangka, ubi kayu, jati, cengkeh, duwet, lamtoro, sengon, dadap, nibung, kapur barus, cemara, kayu besi, meranti, rasamala, walikukun, kesambi, randu alas, kumpas, akasia, Ficus spp., dan Agzelia sp. Jamur akar putih juga dapat menyerang pupuk hijau, seperti Tephrosia spp. dan Crotalaria spp. Tanaman penutup tanah kacangan yang menjalar (legume creeping cover, LCC) juga rentan terhadap jamur akar ini (Semangun 2000).

Serangan patogen $R$. lignosus menyebabkan akar menjadi busuk dan umumnya ditumbuhi rizomorf cendawan. Gejala tampak pada daun; daun-daun yang semula tampak hijau segar berubah menjadi layu, berwarna kusam, dan akhirnya kering (Pawirosoemardjo 2004). Gejala yang tampak adalah cabang dan pucuk tanaman pala menjadi kering dan beberapa hari kemudian langsung mati menyebabkan produksi minyak, biji dan fuli menurun. Pemerintah dan berbagai lembaga terus berupaya melakukan identifikasi masalah kematian pala dan mencari solusi pemecahannya. Pengendalian hama dan penyakit dilakukan walau upaya tersebut belum dapat dikatakan sangat efektif. Upaya dan langkah konkrit lainnya terhadap pengendalian hama dan penyakit mesti terus dilakukan dengan berbagai riset sehingga ditemukan formulasi efektif untuk pengendalian hama dan penyakit pala secara tuntas ${ }^{2}$. Toke Pala Gampong Batu Itam, Kecamatan Tapaktuan, Tasman meminta pemerintah setempat untuk mencari solusi mengatasi serangan penyakit terhadap tanaman pala petani di sana ${ }^{3}$.

Beberapa teknik pencegahan dan pengendalian penyakit JAP adalah membersihkan sumber infeksi, mencegah meluasnya penyakit, penggunaan pestisida dan penggunaan entomopatogen seperti Saccharomyces cerevisiae dan Trichoderma spp. Menurut Amaria et al. (2013), terdapat 8 isolat antagonis yang diperoleh dari rhizosfer tanaman karet dan berpotensi mengendalikan JAP yaitu 1 isolat Trichoderma virens, 2 isolat Trichoderma hamatum, 2 isolat Trichoderma amazonicum, 1 isolat Penicillium pinophilum, 1 isolat Paecilomyces lilacinus, dan 1 isolat Aspergillus fijiensis.

Beberapa cara pengendalian penyakit jamur akar putih telah dilakukan, diantaranya dengan menghilangkan tunggul-tunggul atau organ tanaman berkayu secara tuntas sebagai sumber infeksi, menanam tanaman penutup tanah jenis leguminosa, pelumasan dan penyiraman fungisida, serta pengendalian dengan menggunakan agens hayati seperti Trichoderma spp. yang bersifat antagonis terhadap patogen (Pawirosoemardjo 2004).

Penyakit jamur akar putih efektif dikendalikan dengan pengendalian hayati menggunakan agens antagonis, seperti Trichoderma spp. (Widyastuti et al. 1998). Eksplorasi pada tanah rhizosfer karet dan kelapa sawit dilakukan dalam penelitian ini, guna mencari cendawan antagonis lainnya yang diharapkan dapat efektif dan stabil bila dilakukan pengendalian penyakit jamur akar putih dengan menggunakan pengendalian hayati. 
Pengendalian hayati adalah pengurangan jumlah inokulum dalam keadaan aktif maupun dorman atau penurunan aktivitas patogen sebagai parasit oleh satu atau lebih organisme yang berlangsung secara alami atau melalui manipulasi lingkungan, inang, antagonis, atau dengan introduksi secara massal satu atau lebih organisme antagonis (Cook \& Baker 1983).

Penelitian mengenai tanaman pala Aceh belum ada, baik dari segi botani maupun hama dan penyakit. Sehingga saat terjadi serangan JAP, tidak diketahui bagaimana mengendalikannya. Tujuan dari penelitian ini adalah 1) menentukan cendawan antagonis terhadap jamur akar putih (Rigodoporus lignosus) dari rhizosfer tanaman pala Aceh (Myristica fragrans Houtt), 2) mengidentifikasi kandungan senyawa antibiotik cendawan antagonis JAP pada tanaman pala Aceh. Berdasarkan uraian di atas, penelitian mengenai eksplorasi dan identifikasi cendawan antagonis JAP yang berasal dari rhizosfer tanaman pala Aceh sangat penting dilakukan.

Berdasarkan uraian diatas maka perlu dilakukan penelitian tentang cendawan antagonis terhadap jamur akar putih (JAP) sehingga dapat menentukan spesies cendawan antagonis terhadap jamur akar putih (JAP) yang disebabkan oleh Rigidoporus lignosus dari rhizosfer tanaman pala Aceh.

\section{METODE}

Penelitian ini dilakukan mulai bulan Mei sampai dengan November 2018. Tempat penelitian antara lain, kegiatan pengambilan sampel dilakukan di 3 perkebunan pala di Aceh Selatan, Laboratorium Umum Fakultas Pertanian, Laboratorium Terpadu Universitas Teuku Umar dan Laboratorium Balai Pengawasan dan Sertiifkasi Benih Tanaman Pangan dan Hortikultura, Pulo Ie, Nagan Raya.
Bahan yang digunakan dalam penelitian meliputi: media potato dextrose agar (PDA), aquades, kapas, aluminium foil, alkohol 70\%, chlorine, spiritus, sampel tanah di bawah tegakan pohon pala sehat, sampel akar pohon pala yang terinfeksi JAP, plastic wrap. Peralatan digunakan dalam penelitian meliputi: autoclave, kabinet laminar air flow, corebore, mikroskop, termometer, cawan petri, tabung reaksi, vortex, oven, pipet tetes, hot plate, timbangan analitik, erlenmeyer.

Penelitian ini terdiri atas 6 kegiatan yaitu: (1) pengambilan sampel tanah di bawah tegakan pohon sehat dan bagian akar tanaman terinfeksi JAP; (2) isolasi JAP dari akar tanaman pala yang terinfeksi menggunakan metode tanam langsung (Gandjar dan Syamsurizal 2006); (3) isolasi cendawan antagonis dengan teknik pengenceran (Johnson et al. 1960); (4) uji antagonis menggunakan metode dual culture; (5) uji kemampuan cendawan antagonis; (6) identifikasi cendawan antagonis.

1. Pengambilan sampel di lapangan

Pengambilan sampel di lapangan dilakukan dengan menggunakan metode Purposive Random Sampling. Sampel diambil dari tanah perakaran tanaman pala yang tumbuh sehat. Pengambilan sampel tanah yaitu dengan cara menggali tanah pada kedalaman 10-20 $\mathrm{cm}$ di sekitar rizosfir. Penggalian tanah menggunakan bor belgi dan diambil masing-masing sebanyak $1 \mathrm{~kg}$. Kegiatan ini dilakukan beberapa titik. Selanjutnya, tanah dimasukkan ke dalam kantong plastik dan diberi label tanggal pengambilannya. Sampel tersebut dibawa ke laboratorium untuk diidentifikasi lebih lanjut. Sampel tanah diambil pada lima titik dengan sistem diagonal.

\section{Isolasi JAP}

Isolasi dari akar yang terserang dilakukan dengan metode Gandjar dan 
Syamsurizal (2006): Sampel akar dicuci dengan aquades steril mengalir sampai bersih dan dikeringkan dengan kertas tissue. Sampel akar dipotong secara aseptik dengan pisau menjadi potongan-potongan kurang lebih $1 \mathrm{~cm}$, permukaan potongan disterilkan dengan cara merendam dalam chlorine selama 2 menit, selanjutnya dikeringkan dengan kertas tissue steril dan dibilas kembali dengan aquades steril. Setiap potongan sampel akar diletakkan cawan petri yang telah berisi media (PDA), diinkubasi selama 7 hari pada suhu ruang.

\section{Isolasi Cendawan Antagonis} Isolasi cendawan rhizosfer dilakukan dengan teknik pengenceran dengan dua ulangan. Sebanyak $10 \mathrm{~g}$ contoh tanah disuspensikan ke dalam labu Erlenmeyer yang telah diisi $90 \mathrm{ml}$ air destilata dan diguncang menggunakan shaker dengan kecepatan $120 \mathrm{rpm}$ selama 15 menit. Suspensi yang dihasilkan segera dibuat seri pengenceran hingga tingkat pengenceran $10^{-5}$ dengan mengambil $1 \mathrm{ml}$ suspensi dan dimasukkan ke dalam tabung reaksi berisi $9 \mathrm{ml}$ air destilata. Masingmasing seri pengenceran tersebut diambil sebanyak $0,1 \mathrm{ml}$ suspensi dan dibiakkan pada media PDA. Tiap koloni cendawan yang tumbuh dikelompokkan berdasarkan bentuk dan warna koloni, kemudian dimurnikan. Semua mikroorganisme yang diperoleh diuji potensi antagonismenya terhadap $R$. lignosus. Uji antagonisme dilakukan dengan metode uji ganda pada media PDA.

\section{Uji Cendawan Antagonis}

Uji antagonis antara kandidat cendawan antagonis dengan Jamur Akar Putih (JAP) sebagai patogen dilakukan dengan menggunakan metode uji ganda (dual culture) pada media PDA termodifikasi. Pada pengujian ini media PDA yang digunakan dimasukkan antibiotik kloramfenikol yang mempunyai spektrum anti bakteri yang luas. Kandidat cendawan antagonis diinokulasikan pada media dengan jarak $3 \mathrm{~cm}$ dari koloni Jamur Akar Putih (JAP) yang berumur 7 hari setelah inokulasi (hsi). Diameter masing- masing cendawan uji sebesar $3 \mathrm{~mm}$. Tiap pengujian dilakukan tiga kali ulangan. Pengamatan dilakukan dengan mengukur jari-jari koloni cendawan $R$. lignosus yang menjauhi koloni cendawan kandidat (R1) dan jari-jari koloni cendawan $R$. lignosus yang mendekati kandidat antagonis (R2), serta menghitung penghambatan kandidat agens antagonis (I). Pe ngamatan dilakukan setiap hari hingga hari kesembilan setelah kandidat cendawan antagonis ditanam.

\section{Uji Kemampuan Antagonis}

Besarnya pengaruh penghambatan agens antagonis terhadap patogen dihitung menggunakan rumus persentase:

$$
I=\frac{(\mathrm{R} 1-\mathrm{R} 2)}{\mathrm{R} 1} \quad \mathrm{x} 100 \%
$$

Keterangan:

I : Persentase penghambatan cendawan antagonis (\%)

R1 : Jari-jari koloni $R$. lignosus yang menjauhi koloni cendawan kandidat antagonis

R2 : Jari-jari koloni $R$. lignosus yang mendekati kologi cendawan kandidat antagonis

Catatan: bila koloni pertumbuhan $R$. lignosus sudah tertutup oleh koloni kandidat antagonis, maka dianggap persentase penghambatan cendawan antagonis $(\mathrm{I})=100 \%$. 


\section{Identifikasi Cendawan Antagonis}

Cendawan yang memiliki nilai persen penghambatan yang tinggi terhadap patogen $R$. lignosus dimurnikan menggunakan media PDA dan media MEA untuk dilakukan identifikasi sementara di bawah compound microscope (perbesaran 400x). Identifikasi dilakukan dengan melihat penciri hifa dan percabangan, pembentukan konidium atau spora, serta bentuk konidiumnya. Identifikasi cendawan menggunakan kunci determinasi Barnett \& Hunter (1998), Watanabe (2002), dan "Doctor Fungi" (http://nt.ars-grin.gov/).

\section{HASIL DAN PEMBAHASAN}

1. Isolasi jamur akar putih (R. lignosus) pada tanaman pala

Hasil isolasi menunjukkan bahwa hanya terdapat satu isolat fungi yang tumbuh dari akar tanaman pala yang bergejala. Penampakan makroskopis fungi yang tumbuh tersebut sesuai dengan penampakan makroskopis jamur akar putih, namun masih harus dilakukan pengamatan secara mikroskopis terhadap fungi tersebut. Dari penampakan mikroskopis dapat dilihat bentuk dan warna konidia fungi ini kemudian disesuaikan dengan buku kunci identifikasi.

Berdasarkan Gambar 1, 2 dan 3 dapat dilihat penampakan makroskopis yang sama dari kegiatan isolasi akar yang terinfeksi JAP. Penampakan makroskopis JAP memiliki miselium berwarna putih. Warna kuning yang tampak pada gambar merupakan warna senyawa chlorine yang digunakan untuk sterilisasi sampel akar.

Penampakan makroskopis isolat yang diperoleh dari akar tanaman pala sakit asal Tapak Tuan disajikan pada Gambar 1.

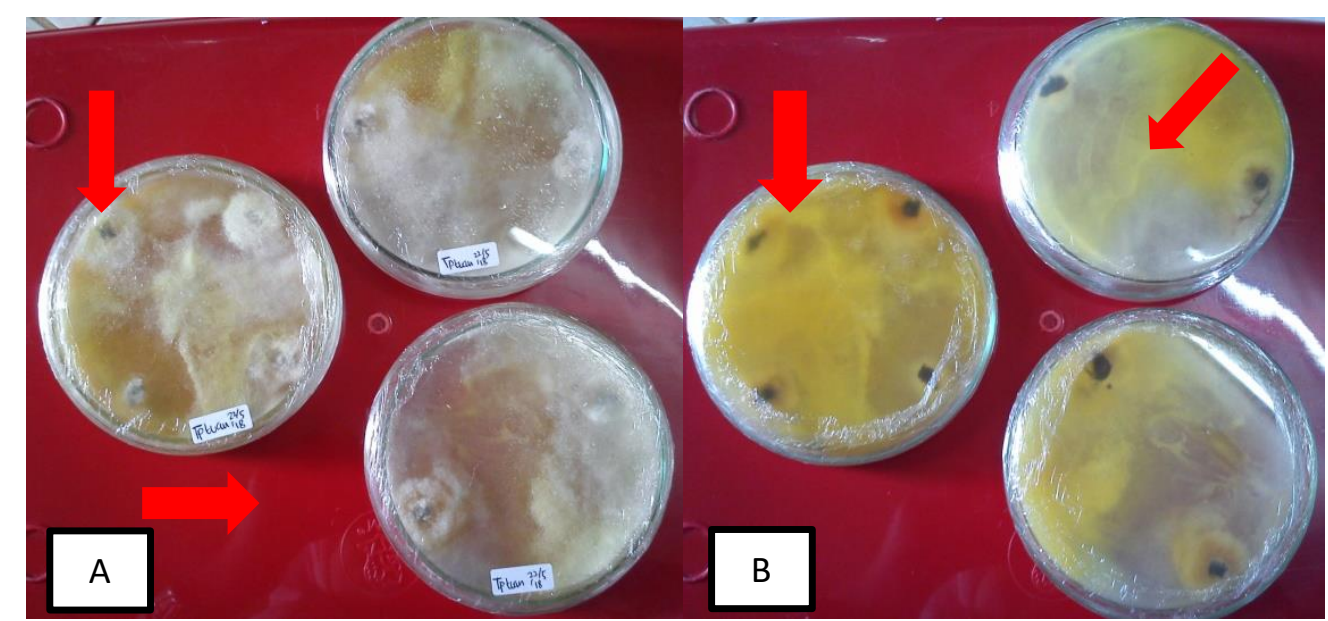

Gambar 1. (A) penampakan makroskopis dari bagian depan; (B) penampakan makroskopis dari bagian belakang cawan. Tanda panah menunjukkan isolat

Penampakan makroskopis isolat yang diperoleh dari akar tanaman pala sakit asal Meukek disajikan pada gambar 2. 


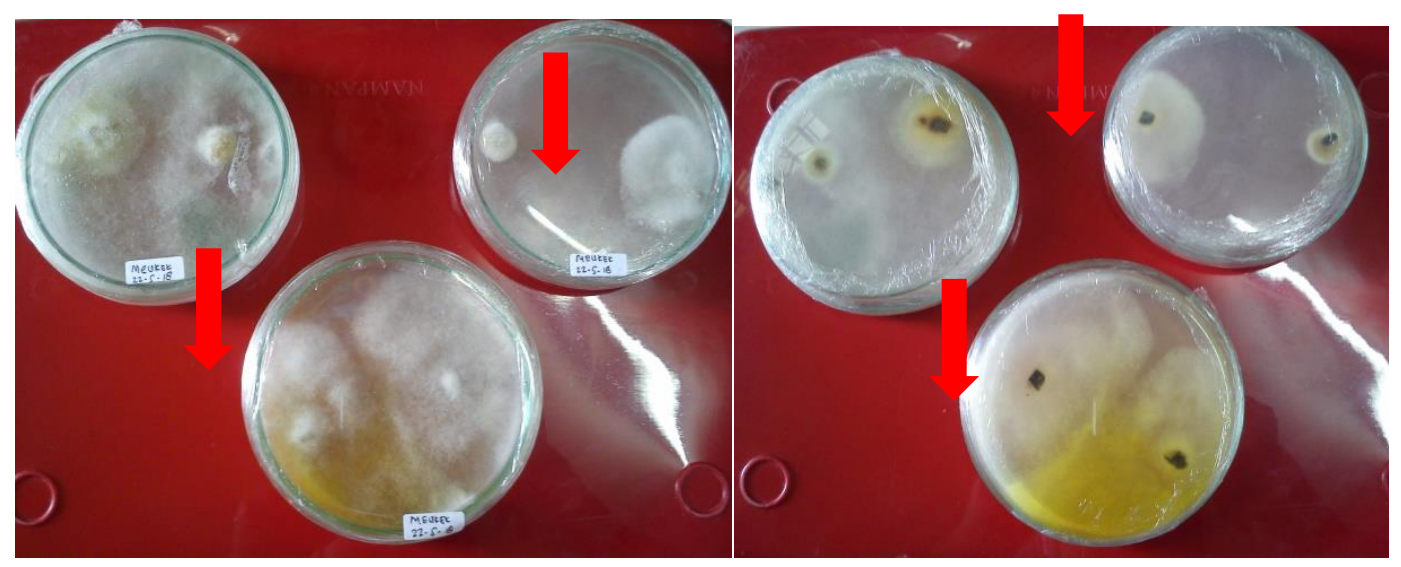

Gambar 4. (A) penampakan makroskopis dari bagian depan; (B) penampakan makroskopis dari bagian belakang cawan. Tanda panah menunjukkan isolat

Penampakan makroskopis isolat yang diperoleh dari akar tanaman pala sakit asal Samadua disajikan pada Gambar 3.

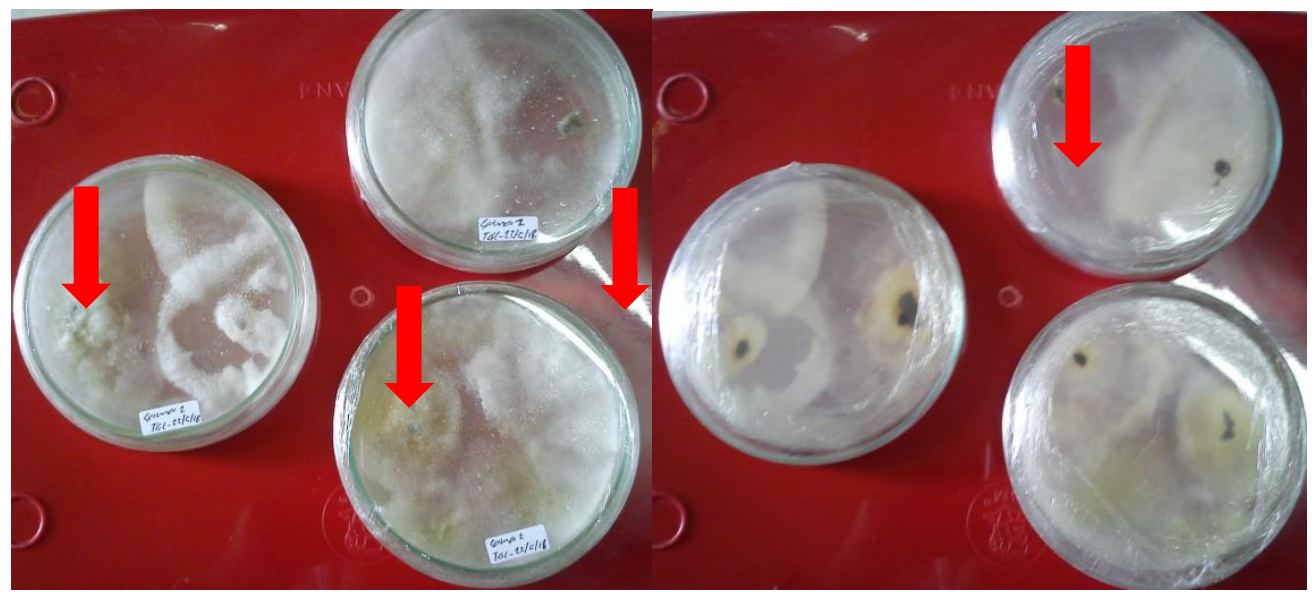

Gambar 5. (A) penampakan makroskopis dari bagian depan; (B) penampakan makroskopis dari bagian belakang cawan. Tanda panah menunjukkan isolate

2. Isolasi cendawan antagonis dari rhizosfer tanaman pala sehat

Hasil isolasi menunjukkan adanya cendawan antagonis, hal ini diketahui dari penampakan makroskopis dari masingmasing fungi tersebut, namun belum bisa diambil kesimpulan genus dari fungi tersebut. Untuk identifikasi genus, perlu dilakukan identifikasi lebih lanjut menggunakan mikroskop sehingga dapat diperoleh informasi mengenai bentuk dan ukuran konidia serta ciri khas lainnya.

Penampakan makroskopis cendawan antagonis asal Tapak Tuan disajikan pada Gambar 4. 


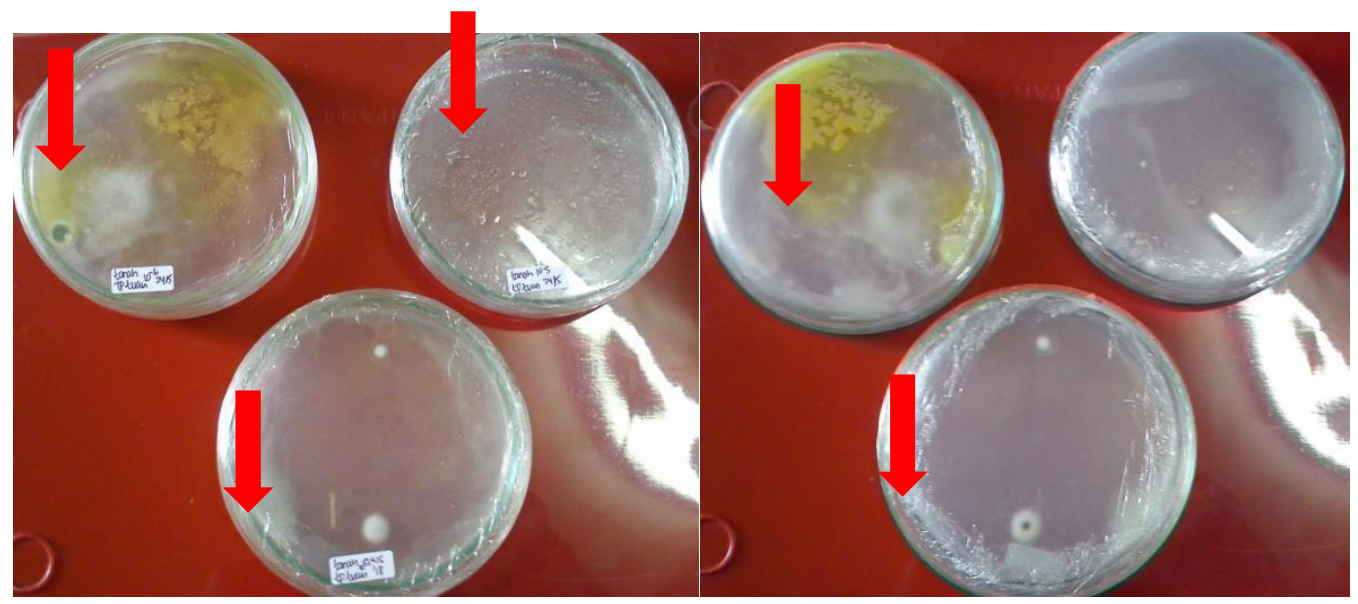

Gambar 4. (A) penampakan makroskopis dari bagian depan; (B) penampakan makroskopis dari bagian belakang cawan. Tanda panah menunjukkan isolat

Penampakan makroskopis cendawan antagonis asal Meukek disajikan pada Gambar 5.
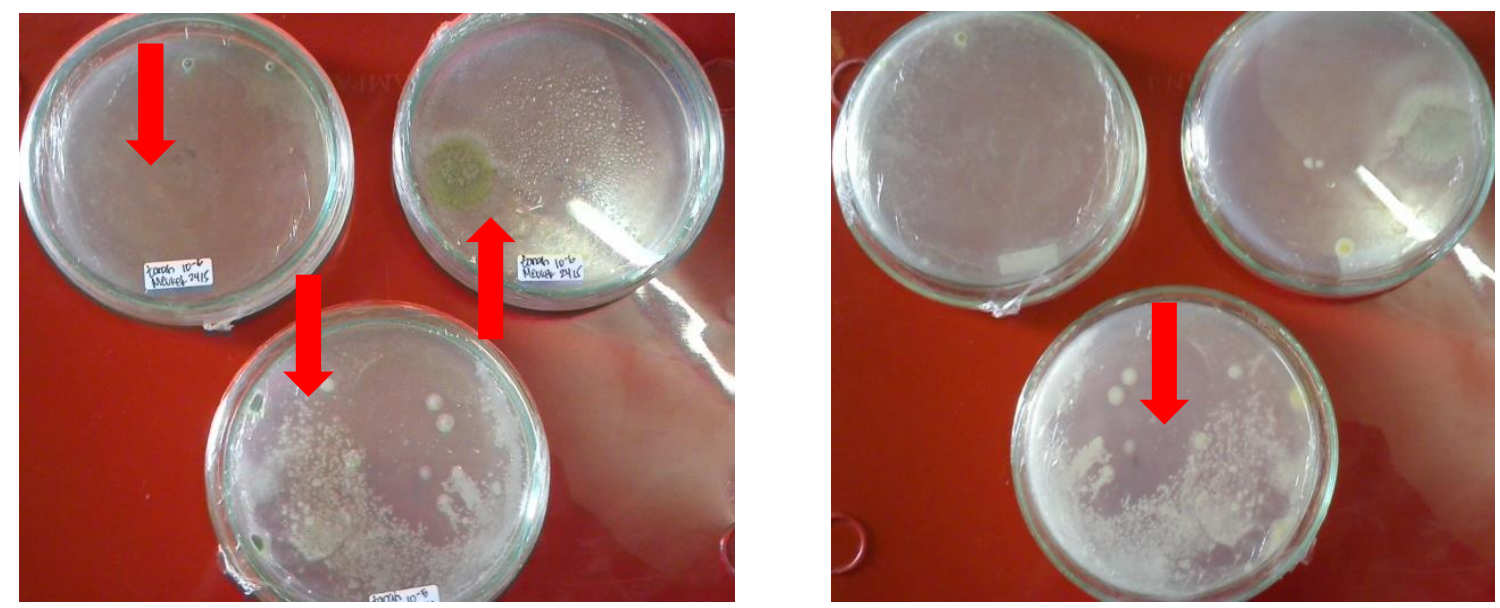

Gambar 5. (A) penampakan makroskopis dari bagian depan; (B) penampakan makroskopis dari bagian belakang cawan. Tanda panah menunjukkan isolat.

Penampakan makroskopis cendawan antagonis asal Samadua disajikan pada Gambar 6.
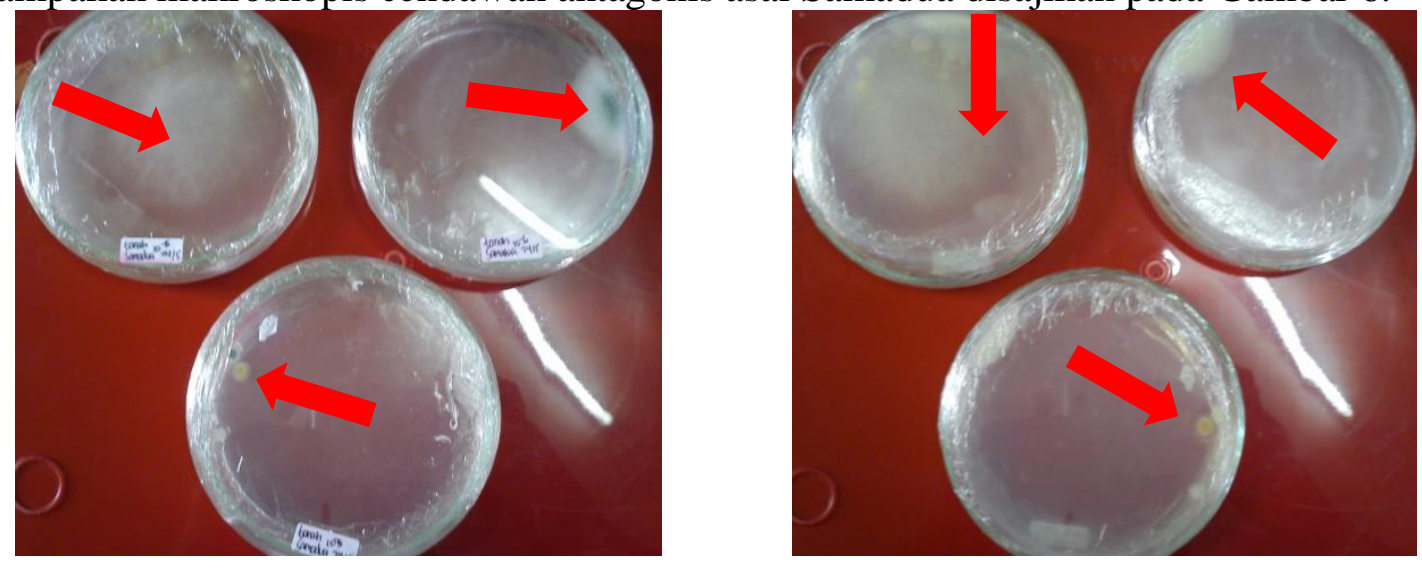

Gambar 6. (A) penampakan makroskopis dari bagian depan; (B) penampakan makroskopis dari bagian belakang cawan. Tanda panah menunjukkan isolat. 
Berdasarkan kriteria-kriteria tersebut, hasil identifikasi untuk sepuluh isolat yang memiliki nilai persen penghambatan yang tinggi terhadap patogen $R$. lignosus Trichoderma spp. mempunyai konidia yang berdinding halus dan berbentuk semi bulat hingga oval pendek, koloni mula- mula berwarna hialin, lalu menjadi putih kehijauan, dan selanjutnya hijau tua terutama pada bagian yang menunjukkan banyak terdapat konidia. Konidiofor dapat bercabang menyerupai piramida yaitu pada bagian bawah cabang lateral yang berulang- ulang, sedangkan semakin ke ujung percabangan menjadi bertambah pendek. Fialid tampak langsing dan panjang terutama pada apeks dari cabang (Domsch et al. 1993). diperoleh tiga jenis cendawan yang berbeda yaitu tiga isolat (isolat $\mathrm{L}, \mathrm{S}$, dan V) yang berasal dari tanah rhizosfer karet dan kelapa sawit merupakan Penicillium sp. tergolong dalam kelas Deuteromycetes yang tidak memiliki spora seksual, ordo Monilliales dengan konidiofor keluar bebas dari miselia, famili Monililliaceae dengan miselia tidak berwarna atau berwarna cerah. Penicilium sp. biasanya bersepta, badan buah berbentuk seperti sapu yang diikuti sterigma dan konidia yang tersusun seperti rantai. Konidia pada hampir semua spesies saat masih muda berwarna hijau kemudian berubah menjadi kecoklatan (Domsch et al. 1993).

Tabel 1. Penghambatan Cendawan Antagonis Terhadap Jamur Akar Putih (JAP)

\begin{tabular}{|c|c|c|c|c|c|c|}
\hline No & Jenis/Kode & \multicolumn{3}{|c|}{ \% Daya Hambat } & Total & Rerata \\
\hline & & U1 & U2 & U3 & & \\
\hline 1 & TP 10-6 2(2) & 55.99 & 59.98 & 15.78 & 131.74 & $43.91 \mathrm{a}$ \\
\hline 2 & ТP 10-6 1(1) & 34.32 & 44.98 & 17.54 & 96.84 & $32.28 \mathrm{a}$ \\
\hline 3 & ТP $10-53(2)$ & 46.89 & 29.99 & 25.86 & 102.74 & $34.25 \mathrm{a}$ \\
\hline 4 & TP 10-5 1 & 21.41 & 43.07 & 35.25 & 99.72 & $33.24 \mathrm{a}$ \\
\hline 5 & TP $10-52$ & 35.25 & 89.96 & 0 & 125.21 & $41.74 \mathrm{a}$ \\
\hline
\end{tabular}

Pada hari pertama nampak
perkembangan koloni isolat kandidat
antagonis uji belum menghambat koloni
cendawan $R$. lignosus secara nyata. Masing-
masing isolat uji dalam uji ganda memiliki
diameter koloni yang masih kecil $( \pm$
dibawah 80\%), hampir sama dengan
diameter koloni $R$. lignosus dan belum
terjadi kontak langsung antara kedua
koloni.


Interaksi antara kedua koloni terjadi pada empat hsi cendawan kandidat antagonis. Pada saat itu, diamater koloni kandidat antagonis sudah jauh lebih besar dari diameter koloni patogen uji. Selain terjadi penghambatan perkembangan koloni $R$. lignosus, beberapa koloni isolat kandidat antagonis uji sudah mampu tumbuh di atas koloni patogen uji (over growth). Hal ini menunjukkan adanya hiperparasitisme, sebelum terjadi antagonis pada koloni patogen nampak adanya zona penghambatan serta kompetisi ruang dan nutrisi oleh kandidat antagonis. Adanya zona penghambatan menunjukkan terjadi

Mekanisme hiperparasit menunjukkan agens antagonis secara langsung memarasit dan mengambil makanan dari patogen uji. Mekanisme antibiosis yangdilakukan oleh agens antagonis bila agens tersebut menghasilkan suatu metabolit yang bersifat toksik bagi organisme lainnya sehingga dapat menghambat pertumbuhan dan mematikan inangnya. Mekanisme lisis adalah istilah umum untuk peristiwa penghancuran, desintregasi, disolusi, atau dekomposisi materi biologi yang dilakukan oleh enzim. Sedangkan mekanisme kompetisi merupakan persaingan tumbuh antar antagonis dan patogen uji untuk mendapatkan nutrisi dan ruang yang ketersediaannya terbatas (Cook \& Baker 1983). Trichoderma spp. mempunyai daya antagonistik yang tinggi dan dapat mengeluarkan toksik, sehingga dapat menghambat bahkan mematikan cendawan lain dan beberapa isolat Trichoderma spp. mampu tumbuh di atas isolat jamur akar putih (Widyastuti et al. 1999). Cendawan tersebut merupakan cendawan antagonis utama yang digunakan dalam pengendalian berbagai penyakit pada berbagai tanaman (Monte \& Llobell 2003; Ha 2010).

\section{KESIMPULAN}

Isolat yang berasal dari akar tanaman pala sakit (terserang JAP) menunjukkan penampakan makroskopis yang sama baik asal Tapak tuan, Meukek maupun Samadua. Terdapatnya beberapa genus cendawan antagonis asal rhizosfer tanaman pala sehat baik di Tapak tuan, Meukek dan Samadua.

Dari rhizosfer di areal pala diperoleh 5 isolat kandidat antagonis, memiliki kemampuan antagonisme in vitro yang tinggi terhadap patogen $R$. lignosus. Hasil identifikasi menunjukkan isolat 1, 2, dan 3 adalah Trichoderma spp, dan isolat 4 dan 5, adalah Gliocladium virens. Mekanisme antagonis yang dilakukan oleh $T$. harzianum dan $G$. virens adalah hiperparasit, antibiosis, lisis, dan kompetisi ruang. Sedangkan mekanisme antagonis yang dilakukan oleh Trichoderma spp adalah kompetisi ruang.

\section{DAFTAR PUSTAKA}

${ }^{1)}$ Informasi dari internet: http://litbang.pertanian.go.id. Diakses pada 30 Juni 2017.

${ }^{2)}$ Informasi dari internet: www.serambiindonesia.com. Diakses pada 30 Juni 2017.

${ }^{3)}$ Informasi dari internet: www.beritakini.com. Diakses pada 30 Juni 2017.

Agrios GN. 2005. Plant Pathology. Ed ke5. London: Elsevier Academic Press.

Amin F, Razdan VK, Mohiddin FA, Bhat KA, Banday S. 2010. Potential of Trichoderma species as biocontrol agents of soil borne fungal propagules. J Phytol 2(10):38-41.

Amaria W, Taufiq E, Harni R. 2013. Seleksi dan identifikasi jamur antagonis sebagai agens hayati jamur akar putih (Rigidoporus microporus) pada tanaman karet. Buletin RISTRI. 4 (1): 55-64. 
Barnet HL, Hunter BB. 1998. Illustrated Genera of Imperfect Fungi. 4ed. APS Pr. Minessota-USA.

Birkinshaw JH, Raistrick H, Smith G. 1942. Fumaryl-dl-alanine (Fumaromono- $d l$-alanide), a metabolic product of Penicillium resticulosum sp. nov. Di dalam: Studies in the Biochemistry of Micro-organisms 7:829-835.

Cook RJ, Baker KF. 1983. The Nature and Practice of Biological Control of Plant Patogen. USA: The American Phytopathological Society.

Domsch KH, Gams W, Anderson TH. 1993. Compendium of Soil Fungi. IHW-Verlag.

Farid AM, Lee SS, Maziah Z, Rosli H, Norwati M. 2006. Root rot in tree species other than Acacia. Di dalam: Potter et al., editor. Heart rot and root rot in tropical Acacia plantations. Proceedings of a Workshop Held; Yogyakarta, 7-9 February 2006. Canberra: ACIAR Proceedings. 124:hlm 60-66.

Febbiyanti TR. 2012. Penapisan jamur dan bakteri antagonis terhadap jamur akar putih (Rigidoporus microporus) dari rhizosfer tanaman lidah mertua (Sansevieria trifasciata Prain). Jurnal Penelitian Karet. 30 (1): 1 - 11.

Gandjar I dan W Syamsurizal. 2006. Mikologi Dasar dan Terapan. Yayasan Obor Indonesia. JakartaIndonesia.

Ha TN. 2010. Using Trichoderma species for biological control of plant pathogens in Vietnam. ISSAAS 16(1):17-21.

Harman GE. 2000. Myths and dogmas of biocontrol changes in perception derived from research on Trichoderma harzianum. Plant Dis 84(4):377-391.
Holliday P. 1996. Pioneer of root disease control in Hevea rubber. Mycologist 10(2):66-68.

Jayasuriya KE dan BI Thennakoon. 2007. Biological control of Rigidoporus microporus, The cause of white root disease in rubber. Cey. J. Sci. (Bio. Sci.) 36 (1): 916.

Johnson ER, Vidyadaran MK. 1960. An evaluation of different sites for measuring fat thickness in the beef carcass to determine carcass fatness. Aust. J. Agric. Res. 32: 9991007.

Kaewchai S dan K Soytong. 2010. Application of biofungicides against Rigidoporus microporus causing white root disease of rubber trees. Journal of Agricultural Technology. 6 (2): 349-363.

Paulitz TC, Linderman RG. 1991. Lack of antagonism beetwen the biocontrol agent Gliocladium virens and vesicular arbuscular mycorrhizal fungi. New Phytol (117):303-308.

Retnosari E. 2011. Identifikasi penyebab busuk pangkal batang Jeruk (citrus spp.) serta uji antagonisme in vitro dengan Trichoderma harzianum dan Gliocladium virens [skripsi]. Bogor: Fakultas Pertanian, Institut Pertanian Bogor.

Rosyali DR. 2016. Identifikasi sifat fisik, mekanik dan morfologi buah pala (Myristica fragrans Houtt) dari Desa Batu Kramat Kecamatan Kota Agung Kabupaten Tanggamus selama penyimpanan. Skripsi. Universitas Lampung, Bandar Lampung.

Rozali G. 2015. Penapisan jamur antagonis indigenus rizosfir kakao (Theobroma cacao Linn.) yang berpotensi menghambat pertumbuhan jamur Phytophthora palmivora Butler. Skripsi. Universitas Andalas, Padang. 
Semangun H. 2000. Penyakit-Penyakit Tanaman Perkebunan di Indonesia. Ed ke-4. Yogyakarta: Gadjah Mada University Press.

Sinaga MS. 1993. Prospek Gliocladium sebagai agen biokontrol patogen tular tanah. Agrotek 1(2):4-7.

Wahyuni, M., M. Sembiring, dan H. Doni. 2011. Efektifitas biofungsida Triko
Sp plus terhadap pencegahan jamur akar putih (Rigidoporus lignosus) di pembibitan batang tanaman karet (Hevea brasilliensis). Jurnal Penelitan STIPAP.

Watanabe T. 1994. Pictorial Atlas of Soil and Seed Fungi Morphologies of Cultured Fungi and Key to Species. CRC Pr. London-Inggris. 